\title{
Interaksi keluarga dan kelompok sebaya menstimulasi strategi pengambilan keputusan berkuliah sembari bekerja
}

\author{
Timotius Saliman', Rustono Farady Marta ${ }^{2}$, Sugeng Wahjudi ${ }^{3}$ \\ ${ }^{1}$ Universitas Bunda Mulia, Tangerang, Indonesia \\ ${ }^{2,3}$ Universitas Bunda Mulia, Jakarta, Indonesia
}

\begin{abstract}
ABSTRAK
Pendidikan merupakan suatu hal yang perlu untuk dimiliki oleh manusia dalam kehidupannya untuk dapat mengembangkan dirinya dari ketertinggalan dan berkeinginan untuk maju. Semakin bertambahnya usia maka akan semakin banyak pula manusia itu belajar untuk memenuhi kebutuhannya melaui proses belajar. Terutama di Indonesia yang memiliki jenjang pendidikan dari SD, SMP, SMA, sampai tingkat Universitas untuk memenuhi kebutuhan belajar masyarakatnya. Sayangnya banyak masyarakat yang tidak menempuh seluruh jenjang pendidikan bahkan sampai tingkat Universitas. Dibutuhkan motivasi serta komunikasi yang baik antara orangtua dan anak agar timbul kesadaran pentingnya melanjutkan pendidikan sampai jenjang Universitas. Di samping itu anak gemar menghabiskan waktunya untuk berinteraksi dengan teman sebayanya. Penelitian ini bertujuan untuk mengetahui dampak komunikasi interpersonal orangtua dan anak dapat mempengaruhi strategi pengambilan keputusan berkuliah sambil bekerja secara dominan, atau justru interaksi kelompok sebaya. Penelitian ini dilakukan menggunakan pendekatan kuantitatif dengan metode survei untuk mengetahui pengaruh interaksi keluarga khususnya komunikasi interpersonal orangtua dan anak juga komunikasi kelompok sebaya, terhadap strategi pengambilan keputusan berkuliah sembari bekerja. Responden penelitian ini adalah 89 mahasiswa Universitas Bunda Mulia. Hasil dari penelitian dengan variabel komunikasi interpersonal orang tua dan anak memiliki pengaruh yang lebih besar dan signifikan sebesar $62,1 \%$ dibandingkan dengan variabel interaksi kelompok sebaya dalam mempengaruhi variabel keputusan berkuliah sembari bekerja.
\end{abstract}

Kata-kata kunci: Interaksi keluarga; kelompok sebaya; strategi pengambilan keputusan; berkuliah; bekerja

\section{Family and peer group interaction stimulates decision-making strategies for studying while working}

\begin{abstract}
Education is something that humans need to have in their lives to be able to develop themselves from being left behind and wanting to move forward. As people get older, more and more people will learn to fulfill their needs through the learning process, especially in Indonesia, which has educational levels from elementary, junior high, high school, to university level to meet the learning needs of its community. Unfortunately, many people do not take all levels of education even to the university level. It takes motivation and good communication between parents and children in order to raise awareness of the importance of continuing education to the university level. In addition, children like to spend their time interacting with their peers. This research aims to know the impact of interpersonal communication between parents and children can influence decisionmaking strategies to study while working predominantly or even peer group interactions. This research was conducted using a quantitative approach with a survey method to determine the effect of family interactions, especially interpersonal communication between parents and children as well as peer group communication, on decision-making strategies for studying while working. Respondents of this research are 89 students of Bunda Mulia University. The results of the study with the parent and child interpersonal communication variable had a greater and more significant influence of $62.1 \%$ than the peer group interaction variable in influencing the variable Study Decision while Working.
\end{abstract}

Keywords: Family interaction;peer group;decision-making strategies;studying while working

Korespondensi: Timotius Saliman., S.E. Magister Ilmu Komunikasi Universitas Bunda Mulia. Jl. Jalur Sutera Barat Kav. 7-9, Alam Sutera, Tangerang, 15143.Email: tsaliman@bundamulia.ac.id 


\section{PENDAHULUAN}

Sesuatu hal yang perlu untuk dimiliki oleh setiap manusia adalah berpendidikan. Pendidikan merupakan sesuatu yang sudah menjadi kebutuhan bagi manusia untuk dapat mengembangkan dirinya dari ketertinggalan dan berkeinginan untuk maju (Nurkholis, 2013). Proses pendidikan yang baik akan membentuk setiap manusia yang berilmu serta dapat mengembangkan berbagai potensi yang dimiliki di dalam dirinya. Proses belajar yang baik akan mampu mengasah hal tersebut. Banyak hal yang perlu dipelajari oleh setiap manusia di dalam kehidupan sehari-hari.

Berbagai jenjang pendidikan dibuat untuk memudahkan manusia belajar secara bertahap yang disesuaikan dengan usia dan kebutuhannya (Sophya, 2014). Semakin bertambahnya usia maka akan semakin banyak kebutuhan yang diperlukan, sehingga makin banyak pula manusia itu belajar untuk memenuhi kebutuhannya melaui proses belajar (Alawiyah, 2017). Indonesia memiliki beberapa tingkatan dalam jenjang pendidikan, yaitu dimulai dari Sekolah Dasar (SD), Sekolah Menengah Pertama (SMP), Sekolah Menengah Atas (SMA) atau Sekolah Menengah Kejuruan (SMK), hingga ke jenjang pendidikan ke tingkat Universitas atau Perguruan Tinggi.

Di Indonesia sendiri, para peserta didik diwajibkan untuk belajar dengan mengikuti pembelajaran di sekolah selama 12 tahun seperti yang tertuang pada Peraturan Menteri Pendidikan dan Kebudayaan Nomor 19 Tahun 2016 yang menyatakan bahwa akan meningkatkan akses untuk mendapatkan layanan pendidikan sampai tamat pendidikan tingkat menengah dalam rangka mendukung pelaksanaan pendidikan menengah universal/ rintisan wajib belajar dua belas tahun (Kementerian Pendidikan dan Kebudayaan, 2016). Semua itu dimaksudkan untuk ke depannya seluruh peserta didik memiliki bekal yang baik berupa ilmu pengetahuan untuk menghadapi perkembangan yang ada dengan baik (Laksana, 2005).

Sayangnya proses pendidikan selama dua belas tahun yang ditempuh dari jenjang Sekolah Dasar (SD), Sekolah Menengah Pertama (SMP), dan Sekolah Menengah Atas (SMA) atau Sekolah Menengah Kejuruan (SMK) dirasa kurang cukup dan belum terarah sedemikian rupa. Melihat kekurangan tersebut maka dibutuhkanlah jenjang pendidikan yang lebih tinggi yaitu melalui perguruan tinggi, yang dimana pendidikan yang diperoleh dari perguruan tinggi atau universitas inilah para peserta didik akan mendapatkan berbagai macam ilmu yang lebih mendalam, diberikan wawasan yang lebih luas, serta dapat menambah kemampuan yang berguna untuk ke depannya 
(Thoharudin, Suryanti, \& Sore, 2019).

Berdasarkan data dari Badan Pusat Statistik dari tahun 1997 sampai dengan tahun 2018. Pada tahun 2018 lalu total jumlah mahasiswa di Indonesia mencapai 7 juta jiwa dengan pembagian 4,5 juta jiwa mahasiswa perguruan tinggi swasta dan 2,5 juta jiwa untuk perguruan tinggi negeri. Data yang disajikan oleh Kementerian Riset, Teknologi, dan Pendidikan Tinggi menunjukkan bahwa total mahasiswa aktif dari perguruan tinggi negeri dan perguruan tinggi swasta di Indonesia sebanyak 6.334.058 orang. Berdasarkan pembagian antara jumlah mahasiswa laki-laki dengan jumlah mahasiswa perempuan yaitu sebanyak 1,3 juta orang lakilaki di perguruan tinggi negeri dan 1,7 juta orang laki-laki di perguruan tinggi swasta. Jumlah mahasiswa perempuan masing-masing sebesar 1,6 juta orang baik di Perguruan Tinggi Negeri dan Perguruan Tinggi Swasta.

Perbandingan antara jumlah peserta didik yang melanjutkan ke jenjang perguruan tinggi dengan peserta didik yang tidak melanjutkan ke jenjang perguruan tinggi sangat terlihat perbedaannya, bahwa lebih banyak peserta didik yang tidak melanjutkan ke jenjang perguruan tinggi (Wijaya, 2018). Dalam rangka mengurangi hal tersebut dibutuhkan komunikasi interpersonal antara orang tua dengan anak serta komunikasi dengan kelompok sebaya yang baik agar menimbulkan kesadaran tentang pentingnya melanjutkan pendidikan ke jenjang perguruan tinggi.

Peran orang tua memantau perkembangan peserta didik dalam proses belajar sangat diperlukan dari berbagai segi, seperti dukungan biaya, moral, etika, semangat, serta dorongan emosional. Seperti yang dikatakan oleh (Sasongko \& Marta, 2018), bahwa terdapat kohesivitas dalam komunikasi keluarga terutama relasi diadik antara ayah dengan anaknya. Berdasarkan hal tersebut dibutuhkan adanya komunikasi interpersonal yang baik antara orang tua dan anak (Handayani, 2016). Orangtua merupakan orang terdekat dengan anak yang ada di dalam keluarga. Antara orangtua dan anak seringkali muncul permasalahan serta berbagai macam perdebatan yang dimana masalah tersebut bisa terjadi karena disebabkan oleh kesalahan pahaman dalam berkomunikasi. Oleh karena itu, perlu adanya komunikasi interpersonal yang baik antara orangtua dan anak untuk mengurangi kesalah pahaman dalam berkomunikasi. Adanya sebuah komunikasi yang baik dan lancar antara orang tua dan anaknya maka akan menunjukkan adanya penerimaan orang tua terhadap anaknya (Kuntaraf \& Kuntaraf, 1999). Komunikasi interpersonal dalam keluarga merupakan salah satu faktor yang dapat mempengaruhi keharmonisan keluarga (Dina, Hadi, \& Rusmawati, 2019). 
Komunikasi verbal yang dilakukan oleh anggota keluarga mempengaruhi kepuasan anggota keluarga, di mana komunikasi tersebut tercermin dari cara orang tua dapat membangun komunikasi yang baik dengan anak (Arkandito, Maryani, \& Rahmawan, 2019). Adanya proses komunikasi seseorang dapat mengemukakan isi hati, pendapat, serta gagasan yang ingin disampaikan kepada anggota keluarga khususnya kepada orangtua. Pola komunikasi yang baik akan secara tidak langsung orang tua akan mendukung dan membimbing anaknya, sehingga timbul motivasi dalam diri anak untuk melanjutkan pendidikan.

Motivasi yang telah diberikan oleh orang tua kepada anak tidak semerta-merta membuat anak memiliki keinginan untuk langsung melanjutkan pendidikan ke jenjang lebih tinggi. Seperti halnya di Indonesia sendiri, sebagian lapisan masyarakat memiliki kondisi ekonomi yang terbatas sehingga mendorong individu untu mencari jalan keluar dari masalah keuangan yang dihadapi dengan bekerja terlebih dahulu untuk meringankan beban orangtua dengan bekerja. Meskipun demikian, memang ada sebagian individu lain yang bekerja dengan alasan untuk bisa mengasah kemandirian.

Nilai-nilai yang baik tentang pendidikan perlu diberikan kepada anak supaya mereka menyadari betapa pentingnya pendidikan. Pendidikan yang tersistem dengan baik akan menghasilkan peserta didik yang kompeten, kreatif, dan memiliki tanggung jawab dalam berbagai bidang. Pendidikan merupakan hal yang sangat perlu diberikan kepada setiap orang, karena dengan pendidikan mereka akan mampu beradaptasi terhadap berbagai perubahan serta inovasi. Kemampuan beradaptasi ini sangat penting karena saat ini adalah era teknologi, di mana inovasi berkelanjutan terjadi di segala bidang (Turabik \& Baskan, 2015).

Data jumlah peserta didik yang ada di Indonesia berdasarkan jenjang pendidikan pada Tahun Ajaran 2017/2018 menunjukkan bahwa jumlah peserta didik untuk Sekolah Dasar (SD) pada data tersebut sebanyak 25,49 juta jiwa dari total peserta didik mencapai 45,3 juta jiwa atau sebesar 56,26\%. Adapun jumlah Sekolah Menengah Pertama (SMP) sebesar 10,13 juta jiwa atau sebesar $22,35 \%$ dari total 45,3 juta jiwa peserta didik. Melainkan untuk jumlah peserta didik Sekolah Menengah Atas (SMA) dan Sekolah Menengah Kejuruan (SMK) masingmasing sebesar 4,78 juta jiwa dan 4,9 juta jiwa atau sekitar $10,56 \%$ dan $10,83 \%$ dari total peserta didik sebanyak 45,3 juta jiwa. Sangat penting ditingkatkan akan kesadaran seluruh lapisan masyarakat untuk mau menempuh dan melanjutkan pendidikan ke jenjang yang lebih tinggi supaya memiliki kemampuan serta wawasan yang dibutuhkan untuk dapat diserap oleh setiap badan usaha. 
Berdasarkan data peserta didik tersebut terlihat bahwa para peserta didik sedikit yang memutuskan untuk melanjutkan ke jenjang pendidikan yang lebih tinggi. Hal tersebut bisa disebabkan oleh berbagai faktor misalnya ekonomi, geografi, demografi, dan sosial. Kurangnya pengetahuan mengenai pentingnya pendidikan juga sangat perlu diperhatikan oleh semua lapisan masyarakat. Guna memudahkan mereka untuk mampu bersaing di tengah perkembangan jaman, dibutuhkan pendidikan yang diarahkan sesuai dengan perkembangan yang ada mulai dari sekolah dasar sampai ke perguruan tinggi (Muhardi, 2005).

Perihal melanjutkan pendidikan ke jenjang perguruan tinggi merupakan suatu hal yang menjadi suatu pilihan penting bagi kelompok usia remaja. Masa remaja merupakan masa transisi, di mana usianya berkisar antara 16 sampai 23 tahun atau yang biasa disebut dengan usia yang menyenangkan, di mana terjadi juga perubahan pada dirinya baik secara fisik, psikis, maupun secara sosial (Siregar, Wasidi, \& Shintia, 2018).

Pada kalangan usia remaja baik lakilaki maupun perempuan sama-sama berada dalam usia yang memiliki perkembangan yang kompleks, di mana remaja mulai tumbuh dan sedang mencari identitas diri. Oleh karena itu mereka merupakan usia yang mudah untuk belajar mengenai hal baru dan cepat dalam mengikuti berbagai perkembangan yang ada sekarang ini. Hal ini bisa terjadi oleh karena usia remaja merupakan sebuah masa transisi dari anak-anak menjadi dewasa sehingga memiliki sifat penting yang perlu dimiliki yaitu rasa ingin tahu. Rasa ingin tahu inilah yang memudahkan kalangan usia remaja untuk belajar dan mengenal tentang hal-hal baru yang ada di lingkungannya. Pada dasarnya manusia merupakan makhluk sosial yang membutuhkan komunikasi serta hubungan dengan sesama baik yang memiliki tujuan tertentu ataupun tidak sama sekali. Kontak yang dilakukan ini akan membentuk jaringan komunikasi (Yusriyah, Fathoni, \& Mansyur, 2020).

Peran orangtua dalam berkomunikasi dan mengawasi perilaku anak sangatlah perlu dilakukan oleh setiap orangtua pada masa seperti ini karena berfungsi untuk mengawasi setiap informasi yang diterima oleh anak serta memberi dukungan, semangat, hingga motivasi untuk terus mengembangkan ilmu. Pemantauan yang dilakukan oleh orang tua merupakan sebuah proses interaktif yang akan menghasilkan kesadaran orang tua mengenai berbagai kegiatan anak-anak melalui penggabungan antara pengungkapan diri anak dan permintaan orang tua (Khurana, Bleakley, \& Jordan, 2015). Meskipun orangtua sibuk dalam bekerja yang bertujuan untuk memenuhi kebutuhan hidupnya, tetap saja perlu untuk 
mendidik anaknya secara langsung, karena apabila orangtua tidak mampu untuk mendidik anaknya dengan baik maka anak akan mencari sesuatu yang bisa didapatkan di luar keluarga.

Rasa ketidakpastian terhadap pilihan untuk melanjutkan pendidikan perguruan tinggi menjadi suatu hal yang dapat didiskusikan dalam kelompoknya. Berbagai macam informasi dan pilihan mengenai perguruan tinggi akan didapatkan oleh setiap individu yang turut berkontribusi dalam diskusi kelompoknya. Hal ini dapat mempengaruhi minat setiap individu dalam memutuskan untuk melanjutkan pendidikan ke perguruan tinggi. Setiap anggota kelompok harus bisa memahami terlebih dahulu bagaimana proses evaluasi alternatif sebelum memutuskan untuk bertindak.

Berbagai aspek dijadikan sebagai bahan pertimbangan ketika ingin memutuskan untuk melanjutkan ke perguruan tinggi seperti misalnya, ketersediaan biaya, kebutuhan untuk mencari kerja, tuntutan dari tempat di mana seseorang bekerja, atau tuntutan keluarga. Berbagai macam hal dijadikan pertimbangan sesuai dengan kebutuhannya. Banyak yang memilih untuk melanjutkan pendidikan ke perguruan tinggi tanpa melakukan kegiatan tambahan dengan bekerja. Di sisi lain tidak sedikit juga yang memilih untuk melanjutkan pendidikan ke perguruan tinggi sambil bekerja.

Dalam kehidupan di usia remaja, teman sebaya merupakan sebuah faktor yang sangat berpengaruh. Menurut Harlock, anak remaja lebih banyak menghabiskan waktu bersama dengan kelompok sebayanya, oleh karena itu teman sebaya dapat mempengaruhi sikap, pembicaraan, minat, penampilan, bahkan perilaku lebih besar yang diberikan oleh keluarga (Sari, Hamiyati, \& Rasya, 2019). Teman sebaya juga dapat mempengaruhi seseorang dalam melakukan pengambilan keputusan, karena tidak terlepas dari interaksi yang dilakukan ketika mereka berkumpul, dimana adanya proses berpikir dikembangkan dan diungkapkan. Lebih dari itu berpikir mempengaruhi seseorang dalam bertingkah laku (Hutapea, 2015). Seperti halnya dalam melanjutkan pendidikan ke jenjang perguruan tinggi. Tidak semua anggota dalam kelompoknya akan melakukan suatu hal secara bersama-sama, akan ada anggota kelompok yang tidak melakukan hal seperti yang dilakukan oleh anggota kelompok lainnya. Hal tersebut dikarenakan setiap individu memiliki pendapat, minat, serta perilaku yang tidak seragam antara satu dengan yang lainnya dalam menanggapi sesuatu.

Bukan hanya tugas belajar saja yang menjadi tanggung jawab yang harus dipikul melainkan juga tanggung jawab pekerjaan juga menjadi suatu hal yang harus dipegang. Semua memiliki hal yang mendasari keputusan para remaja untuk melanjutkan pendidikan ke 
perguruan tinggi. Misalnya dikarenakan tuntutan persyaratan jenjang pendidikan minimum yang dikehendaki oleh perusahaan, keinginan untuk memiliki jabatan yang lebih baik, atau hanya sekedar untuk menambah pengalaman.

Peneliti tertarik untuk meneliti fenomena yang ada di suatu Universitas Bunda Mulia, yang mana banyak mahasiswanya yang memutuskan untuk berkuliah pada malam hari atau mereka yang berkuliah sambil bekerja. Tentunya berbagai macam faktor melatar belakangi dan member pengaruh pada mereka dalam memutuskan untuk berkuliah sambil bekerja. Faktor yang dapat menyebabkan memutuskan untuk berkuliah sambil bekerja bisa karena faktor ekonomi, karena keinginan untuk melanjutkan jenjang pendidikan lebih tinggi tetapi terbatas dengan keadaan ekonomi maka diputuskanlah bekerja sambil berkuliah untuk dapat mencukupi biaya perkuliahan. Selain itu bisa juga karena faktor keinginan untuk mencari pengalaman, keinginan untuk belajar untuk mandiri, atau karena tuntutan dari tempat dimana ia bekerja. Oleh karena itu peneliti tertarik untuk meneliti apakah adanya hubungan komunikasi interpersonal orang tua dan anak, interaksi komunikasi kelompok sebaya, terhadap strategi pengambilan keputusan berkuliah sambil bekerja.

Perlu diperhatikan betapa pentingnya bimbingan orangtua terhadap anaknya, terlebih lagi dalam mengawasi pergaulan yang dilakukan oleh anaknya agar anaknya dapat terarah dengan baik sesuai dengan keinginan orangtuanya. Mengacu pada hal tersebut, perlu ada komunikasi yang baik dalam hubungan anak dan orangtua. Peran ayah dan ibu sebagai orangtua dalam mengasuh serta mengendalikan anak dan memiliki keterbukaan dengan baik dapat menghasilkan dampak positif bagi anak (Marta \& Fernando, 2019). Ketika sang anak memiliki keluh kesah mengenai pilihan akan kuliah sambil kerja, orangtua dapat memberikan masukan yang baik serta mengarahkan kepada suatu hal yang seharusnya dilakukan oleh anak tersebut.

Penelitian ini memerlukan pembatasan masalah agar lebih terarah serta terfokus kepada subjek dan objek penelitian, selain itu agar jangkauannya tidak terlalu luas. Penelitian ini dibatasi pada usia remaja antara 16-23 tahun yang sudah bekerja dan memutuskan untuk berkuliah sambil bekerja di Universitas Bunda Mulia angkatan Tahun Ajaran 2019/2020.

\section{METODE PENELITIAN}

Penelitian ini dilakukan menggunakan pendekatan kuantitatif dengan metode survei untuk mengetahui apakah terdapat pengaruh komunikasi interpersonal orangtua dan anak dan interaksi kelompok sebaya, terhadap strategi pengambilan keputusan berkuliah sambil 
kerja. Kasiram menyatakan bahwa penelitian kuantitatif merupakan proses menemukan pengetahuan menggunakan data berupa angka sebagai alat untuk menganalisis mengenai apa yang ingin diketahui (Sutanta, 2019). Peneliti tertarikuntukmengetahuiapayangmenyebabkan individu mengambil keputusan untuk berkuliah sambil bekerja. Mempertanyakan: Apakah komunikasi interpersonal orangtua dan anak serta komunikasi kelompok sebaya dapat mempengaruhi secara langsung atau tidak terhadap perilaku individu dalam memutuskan untuk berkuliah sambil bekerja?

Pada penelitian inikomunikasiinterpersonal orangtuadan anak merupakan variabel $\mathrm{X}^{1}$, interaksi kelompok sebaya merupakan sebagai variabel $\mathrm{X}^{2}$, dan strategi pengambilan keputusan berkuliah sambil kerja merupakan variabel Y.

Paradigma yang dipakai peneliti dalam penelitian ini yaitu paradigma positivis. Paradigma positivis menekankan pada kejadian nyata dan faktual serta dapat dipelajari dan diamati secara ilmiah dan empiris serta dapat dijelaskan dengan cara diselidiki dan analisis yang jelas dan rasional (Aliyu, Bello, \& Kasim, 2014). Penelitian yang terletak dalam paradigma ini bergantung pada logika deduktif, perumusan hipotesis, pengujian hipotesis tersebut, menawarkan definisi operasional dan persamaan matematika, perhitungan, ekstrapolasi dan ekspresi, untuk mendapatkan kesimpulan (Kivunja \& Kuyini, 2017).

Penelitian ini menggunakan pendekatan kuantitatifyang dapat digunakan sebagai respons terhadap pertanyaan-pertanyaan relasional variabel dalam penelitian yang dimulai dengan pernyataan masalah dan melibatkan pembentukan hipotesis, tinjauan literatur, dan analisis data kuantitatif (Marvasti, 2018). Dalam penelitian ini peneliti menggunakan analisis descriptive explanatory research yang merupakan sebuah penelitian yang bermaksud untuk menjelaskan kedudukan variabel-variabel yang diteliti serta hubungan antara satu variabel dengan yang lain (Sugiyono, 2015).

Sukamolson menyatakan bahwa terdapat beberapa tipe dalam penelitian kuantitatif, yaitu survei, korelasional, eksperimental, dan kausal komparatif (Apuke, 2017). Pada penelitian ini peneliti melakukan penelitian melalui survey mencakup penggunaan metode pengambilan sampel ilmiah dengan kuesioner yang dirancang untuk mengukur karakteristik populasi tertentu melalui pemanfaatan metode statistik. Ukuran sampel yang layak dalam penelitian adalah antara 30 sampai dengan 500 sampel.

Teknik pengambilan sampel atau sampling bertujuan untuk menentukan sampel dari ukuran sampel yang dijadikan sumber data dalam penelitian (Sutanta, 2019). Teknik penarikan sampel yang diambil oleh peneliti dalam penelitian ini yaitu teknik penarikan 
sampel secara non-probabilitas. Sampling nonprobabilitas merupakan sebuah pengambilan sampel yang tidak semua individu dalam populasi memiliki kesempatan yang sama untuk menjadi anggota sampel (Sutanta, 2019).

Peserta yang diteliti adalah peserta didik usia remaja antara 16 tahun sampai 23 tahun yang sudah memiliki pekerjaan dan berkuliah pada malam hari. Insentif yang diperoleh dari teknik ini adalah penerapannya yang lebih luas, tanpa asumsi pengetahuan sebelumnya tentang populasi dan kebebasannya dari kesalahan klasifikasi di samping kesederhanaan pemahaman (Umar, Hassan Sa'id \& Usman, 2015).

Penelitian ini dilakukan di Universitas Bunda Mulia dengan angkatan Tahun Ajaran 2019/2020 memiliki jumlah mahasiwa yang berkuliah pada malam hari sebanyak 395 mahasiswa. Populasi yang dijadikan sebagai responden, yaitu mereka yang sudah memiliki pekerjaan dan berkuliah di malam hari.

Dalam statistik, populasi merupakan seluruh kelompok yang dimana beberapa informasi harus dipastikan dan populasi tidak hanya terdiri dari orang-orang. Populasi dapat juga berupa populasi ketinggian, bobot, kadar hemoglobin, peristiwa, hasil, selama populasi didefinisikan dengan baik dengan kriteria yang jelas (Banerjee \& Chaudhury, 2010). Menanggapi akan hal tersebut, Elfil \&
Negida (2017) mendefinisikan populasi sebagai kelompok orang yang memiliki karakter atau kondisi yang sama.

Sementara itu, sampel dapat didefinisikan sebagai acak jika setiap individu dalam populasi yang disurvei memiliki kemungkinan yang sama untuk dimasukkan (Banerjee \& Chaudhury, 2010). Williamson (2018) menambahkan bahwa sampel merupakan sebuah elemen yang dipilih berdasarkan total populasi yang akan dipelajari. Sampel adalah bagian dari populasi, untuk melihat itu representatif atau tidak. Jadi dapat disimpulkan bahwa sampel merupakan sebuah elemen yang terdapat pada total suatu populasi yang dipilih secara acak oleh peneliti untuk mewakilkan dari jumlah keseluruhan populasi yang ada.

Penelitian ini berupaya menyimpulkan sementara melalui hipotesis sebagai berikut:

H1: Komunikasi interpersonal orangtua dan anak berpengaruh signifikan terhadap strategi pengambilan keputusan berkuliah sambil bekerja.

H2: Interaksi kelompok sebaya berpengaruh signifikan terhadap keputusan berkuliah sambil bekerja.

H3: Komunikasi interpersonal orangtua dan anak, dan interaksi kelompok sebaya berpengaruh signifikan terhadap strategi pengambilan keputusan berkuliah sambil bekerja. 


\section{HASIL DAN PEMBAHASAN}

Penelitian ini dilakukan di Universitas Bunda Mulia yang berlokasi di Jakarta. Subjek penelitian adalah mahasiswa/i kampus yang sambil bekerja sebanyak 89 orang.

Uji validitas $r$ hitung $>r$ tabel. $R$ tabel dari standar 89 sampel dengan taraf signifikan 5\%= 0.279 dan uji reliabilitas dilihat dari cronbach alpha $>0.60$.

Reliabilitas berkaitan dengan konsistensi suatu ukuran. Peserta yang melengkapi instrumen yang dimaksudkan untuk mengukur motivasi harus memiliki respons yang kirakira sama setiap kali tes selesai (Heale \& Twycross, 2015). Reliabilitas berkenaan dengan konsistensi serta stabilitas sebuah data dalam penelitian. Dalam penelitian kuantitatif, suatu data dapat dinyatakan reliabel apabila dua atau lebih peneliti dalam objek penelitian yang sama menghasilkan data yang sama (Sutanta, 2019).

Dalam rangka menilai konsistensi seluruh skala dapat menggunakan Alfa Cronbach, cara ini menjadi ukuran yang paling banyak digunakan (Hair et al., 2014). Koefisien ini bervariasi dari 0 hingga 1, dan nilai 0,6 maka dinyatakan konsistensi reliabel, apabila kurang maka dianggap tidak reliabel (Malhotra, 2010).

Berdasarkan tabel uji reliabilitas (tabel 1), dapat disimpulkan bahwa nilai Cronbach's Alpha dari variabel komunikasi interpersonal
Tabel 1 Reliabilitas $\mathrm{X}^{1}$ Dan $\mathrm{X}^{2}$

\begin{tabular}{cc}
\hline Variabel & Cronbach's Alpha \\
\hline X1 & 0,774 \\
X2 & 0,622 \\
\hline
\end{tabular}

Sumber: Hasil Penelitian, 2020

orangtua dan anak $\left(\mathrm{X}^{1}\right)$ mencapai 0.774 . Untuk nilai Cronbach's Alpha dari variabel Interaksi Kelompok Sebaya $\left(\mathrm{X}^{2}\right)$ mencapai 0.622. Dapat dinyatakan, uji reliabilitas penelitian Pengaruh Komunikasi Orangtua dan Anak $\left(\mathrm{X}^{1}\right)$ dan Interaksi Kelompok Sebaya $\left(\mathrm{X}^{2}\right)$ terhadap Strategi pengambilan keputusan Berkuliah Sambil Bekerja (Y) dinyatakan reliabel dan konsisten karena nilai Cronbach's Alpha yang didapat $>0.60$.

Berdasarkan tabel persentase (tabel 2) yang menyatakan bahwa komunikasi interpersonal yang dilakukan oleh anak dengan orangtuanya dapat mempengaruhi perilaku mereka dalam mengambil sebuah keputusan khususnya dalam hal berkuliah sambil bekerja, dapat disimpulkan bahwa nilai responden yang setuju sebesar $63 \%$ responden dan sangat setuju sebesar 29\%

Tabel 2 Analisis Persentase Pernyataan $X^{1}$

\begin{tabular}{cc}
\hline${\text { Jawaban pada Pernyataan } \mathbf{X}^{\mathbf{1}}}$ & Persen \\
\hline STS & 1,9 \\
TS & 6,1 \\
S & 63 \\
SS & 29 \\
\hline Total & 100 \\
\hline
\end{tabular}

Sumber: Hasil Penelitian, 2020 
responden, sedangkan responden yang tidak setuju sebesar $6,1 \%$ responden dan sangat tidak setuju sebesar $1,9 \%$ responden.

Mengacu pada hasil penghitungan dapat dinyatakan bahwa komunikasi interpersonal orangtua dan anak $\left(\mathrm{X}^{1}\right)$ dapat mempengaruhi dalam strategi pengambilan keputusan berkuliah sambil bekerja (Y). Terdapat perbedaan antara orang dewasa dengan remaja, dimana remaja akan cenderung lebih memilih sesuatu yang memiliki manfaat jangka pendek meskipun risiko yang harus dilalui terhitung tinggi (Sasson \& Mesch, 2017). Oleh karena itu, peran orangtua dalam membimbing perilaku anaknya sangatlah penting, terlebih lagi dalam mengawasi setiap keputusan yang diambil. Pemantauan yang dilakukan oleh orang tua merupakan sebuah proses interaktif yang akan menghasilkan kesadaran orang tua mengenai berbagai kegiatan anak-anak melalui penggabungan antara pengungkapan diri anak dan permintaan orang tua (Khurana, Bleakley, \& Jordan, 2015).

Tabel 3 Analisis Persentase Pernyataan $X^{2}$

\begin{tabular}{cc}
\hline Jawaban pada Pernyataan $\mathbf{X}^{2}$ & Persen \\
\hline STS & 3 \\
TS & 13 \\
& \\
S & 69 \\
SS & 15 \\
\hline Total & 100 \\
\hline
\end{tabular}

Sumber: Hasil Penelitian, 2020
Berdasarkan tabel persentase (tabel 3) yang menyatakan bahwa interaksi yang dilakukan oleh individu dengan kelompok sebayanya dapat mempengaruhi perilaku mereka dalam mengambil sebuah keputusan khususnya dalam hal berkuliah sambil bekerja. Menurut Harlock, anak usia remaja cenderung untuk menghabiskan waktu dengan kelompok sebayanya, sehingga teman sebaya dapat mempengaruhi sikap, minat, dan bahkan perilaku lebih besar yang diberikan oleh keluarga (Sari, Hamiyati, \& Rasha, 2019). Dapat disimpulkan bahwa nilai responden yang setuju sebesar $69 \%$ responden dan sangat setuju sebesar $15 \%$ responden, sedangkan responden yang tidak setuju sebesar $13 \%$ responden dan sangat tidak setuju sebesar 3\% responden.

Mengacu pada hasil penghitungan dapat dinyatakan bahwa mayoritas responden percaya Interaksi Kelompok Sebaya $\left(\mathrm{X}^{2}\right)$ dapat mempengaruhi dalam Strategi pengambilan keputusan Berkuliah Sambil Bekerja (Y). Hal tersebut bisa terjadi karena mereka cenderung mengkonsumsi konten dari berbagai

Tabel 4 Analisis Persentase Pernyataan Y

\begin{tabular}{cc}
\hline Jawaban pada Pernyataan Y & Persen \\
\hline STS & 4 \\
TS & 14 \\
& \\
S & 60 \\
SS & 22 \\
\hline Total & 100 \\
\hline
\end{tabular}

Sumber: Hasil Penelitian, 2020 
macam platform atau perangkat dan biasanya dipengaruhi juga oleh apa yang dipikirkan oleh teman mereka (Stankevich, 2017).

Berdasarkan tabel persentase (tabel 4) yang menyatakan bahwa pada akhirnya individu memutuskan untuk berkuliah sambil bekerja dan merasa yakin akan pilihannya. Dapat disimpulkan bahwa nilai responden yang setuju sebesar $60 \%$ responden dan sangat setuju sebesar $22 \%$ responden, sedangkan responden yang tidak setuju sebesar $14 \%$ responden dan sangat tidak setuju sebesar $4 \%$ responden. Dapat dinyatakan bahwa mayoritas responden merasa yakin dan memutuskan untuk berkuliah sambil bekerja. Kendati demikian, dampak pekerjaan siswa pada hasil pendidikan harus dipertimbangkan bersama dengan dampaknya pada hasil sosial ekonomi lainnya, di tingkat mikro dan makro (Sasson \& Mesch, 2017). Bukan hanya tugas belajar saja yang menjadi tanggung jawab yang harus dipikul melainkan juga tanggung jawab pekerjaan juga menjadi suatu hal yang harus dipegang.

Pada penelitian ini dilakukan juga uji normalitas. Penggunaan uji normalitas adalah untuk mengetahui sampel yang diambil merupakan data yang berdistribusi normal atau tidak. Uji normalitas terhadap variabel terikat dilakukan melalui Uji Kolmogorov-Smirnov (Ghozali, 2016). Hasil uji normalitas dapat dilihat pada data yang disajikan di bawah ini:
$\mathrm{Uji} \mathrm{K}-\mathrm{S}$

Apabila nilai signifikan Asymp. Sig. $(2$-tailed $)<0.05=$ distribusi tidak normal

Untuk nilai signifikan Asymp. Sig. $(2$-tailed $)>0.05=$ distribusi normal

Data dinyatakan berdistribusi normal jika Asymp. Sig. (2-tailed) >0,05 begitupun sebaliknya data dinyatakan tidak berdistribusi normal jika Asymp Sig. (2- tailed) <0,05. Hasil uji Kolmogorov-Smirnov menunjukkan nilai signifikansi rasio Komunikasi Interpersonal Orangtua dan Anak ( $\left.\mathrm{X}^{1}\right)$ sebesar $0.887>$ 0.05. Pada rasio Interaksi Kelompok Sebaya $\left(\mathrm{X}^{2}\right)$ nilai signifikansi sebesar $0.469>0.05$ dan untuk Strategi pengambilan keputusan Berkuliah Sambil Bekerja (Y) menunjukkan nilai signifikansi sebesar $0.957>0.05$. Dapat disimpulkan bahwa data terdistribusi secara normal.

Tahap selanjutnya adalah uji heteroskedastisitas yang digunakan untuk mengetahui adanya ketidaksamaan varian dari residual untuk semua pengamatan pada model regresi. Pada regresi yang baik seharusnya tidak terjadi heteroskedastisitas.

Penelitian ini menggunakan uji Glejser yaitu uji yang mengusulkan untuk meregres nilai absolut residual terhadap variabel independen dengan persamaan regresi (Ghozali, 2016). Model regresi tidak mengandung heteroskedastistas apabila nilai probabilitas 
signifikansinya $>5 \%$.

Berdasarkan penghitungan uji heterokedastisitas yang telah dilakukan, diketahui bahwa nilai signifikansi variabel komunikasi interpersonal orangtua dan anak $\left(\mathrm{X}^{1}\right)$ memiliki nilai Sig. sebesar 0.289 sehingga nilai tersebut $>$ dari 0.05 dan signifikansi variabel Interaksi Kelompok Sebaya $\left(\mathrm{X}^{2}\right)$ memiliki nilai Sig. $>0.05$ yaitu 0.437 , berdasarkan data tersebut maka dapat disimpulkan bahwa tidak terjadi heterokedastisitas.

Gunamelengkapitahapanujidata, dilakukan juga uji multikolinearitas. Uji multikolinieritas dapat dilihat dari nilai tolerance dan lawannya variance inflation factor (VIF) dengan kriteria terjadi multikolinearitas jika VIF $>10$ dan Tol $<$ 0,1 (Ghozali, 2016). Uji melalui nilai Tolerance dan VIF apabila Tol $>0.1$, maka tidak terjadi multikolinearitas dalam model regresi dan apabila Tol $<0.1$, maka terjadi multikolinearitas dalam model regresi. Selanjutnya apabila nilai VIF $<10$ maka tidak terjadi multikolinearitas dalam model regresi, dan apabila nilai VIF > 10 maka terjadi multikolinearitas dalam model regresi.

Berdasarkan penghitungan uji multikolinearitas yang sudah dilakukan, diketahui bahwa nilai tolerance variabel komunikasi interpersonal orangtua dan anak $\left(\mathrm{X}^{1}\right)$ dan variabel interaksi kelompok sebaya $\left(\mathrm{X}^{2}\right)$ memiliki nilai sebesar 0.918 sehingga nilai tersebut lebih besar dari 0.1 dan VIF kedua variabel memiliki nilai kurang dari 10 yaitu 1.090, berdasarkan data tersebut maka dapat disimpulkan tidak terjadinya multikolinearitas pada variabel komunikasi interpersonal orangtua dan anak $\left(\mathrm{X}^{1}\right)$ maupun variabel interaksi kelompok sebaya $\left(\mathrm{X}^{2}\right)$.

Tahap berikutnya adalah uji autokorelasi. Uji autokorelasi bertujuan untuk mengetahui apakah terjadi korelasi antara suatu periode dengan periode lainnya. Model regresi yang baik adalah yang bebas dari autokorelasi. Model regresi yang baik seharusnya tidak terjadi autokorelasi. Pada penelitian ini menggunakan uji run test. Dasar pengambilan keputusan pada uji run test adalah jika nilai Asymp. Sig (2-tailed) $>0,05$ maka tidak terdapat gejala autokorelasi.

Guna mendeteksi terdapat atau tidaknya autokorelasi adalah dengan melakukan uji Run Test, apabila (Ghozali, 2016) nilai Asymp. Sig. (2-tailed) $<5 \%$ atau 0,05 , maka untuk $\mathrm{H} 0$ ditolak dan Ha diterima. Data residual terjadi secara tidak acak (sistematis), dan apabila nilai Asymp. Sig. (2-tailed) > 5\% atau 0,05, maka untuk H0 diterima dan Ha ditolak. Data residual terjadi secara acak (random).

Berdasarkan penghitungan uji run test yang telah dilakukan, menghasilkan nilai Asymp. Sig adalah $0.524>0.05$, maka dapat disimpulkan bahwa tidak terdapat gejala autokorelasi pada 


\section{Coefficients $^{a}$}

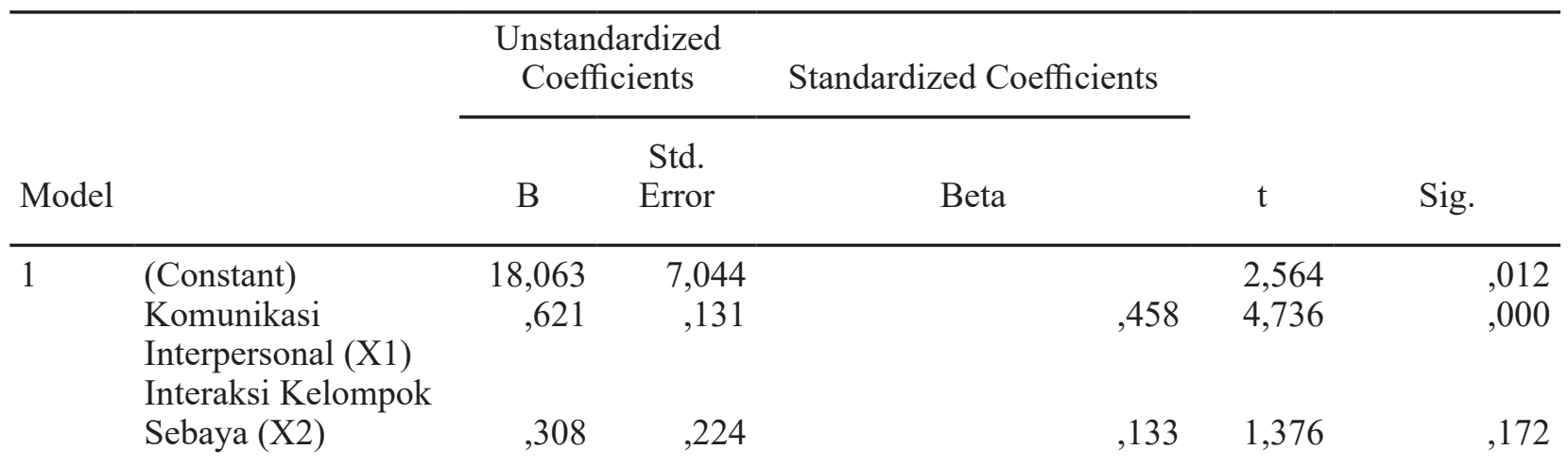

a. Dependent Variable: Pengambilan Keputusan (Y)

variabel komunikasi interpersonal orangtua dan anak $\left(\mathrm{X}^{1}\right)$ maupun variabel interaksi kelompok sebaya $\left(\mathrm{X}^{2}\right)$, yang berarti $\mathrm{H}_{0}$ diterima dan $\mathrm{Ha}$ ditolak dan data residual terjadi secara acak.

Uji t dilakukan untuk menguji bagaimana pengaruh setiap variabel bebas yang ada terhadap variabel terikat dengan membandingkan hasil penghitungan $\mathrm{t}$ hitung dan $\mathrm{t}$ tabel (Hidayat, 2013). Uji t yang dulakukan bertujuan untuk melihat pengaruh dari variabel komunikasi interpersonal orangtua dan anak $\left(\mathrm{X}^{1}\right)$ dan variabel interaksi kelompok sebaya $\left(\mathrm{X}^{2}\right)$ terhadap variabel terikat strategi pengambilan keputusan berkuliah sambil bekerja (Y).

Berdasarkan uji hipotesis yang dilakukan dengan menggunakan Uji t, diketahui nilai Sig. untuk pengaruh komunikasi interpersonal orangtua dan anak $\left(\mathrm{X}^{1}\right)$ terhadap strategi pengambilan keputusan berkuliah sambil bekerja (Y) adalah sebesar $0,000<0,05$ dan nilai t hitung 4,736 > t tabel 1,987, sehingga dapat disimpulkan bahwa H1 diterima yang berarti terdapat pengaruh komunikasi interpersonal orangtua dan anak $\left(\mathrm{X}^{1}\right)$ terhadap strategi pengambilan keputusan berkuliah sambil bekerja (Y). Berdasarkan hal tersebut, Moore (2017) telah mengorientasikan ke dalam tiga kata kunci penting dalam pengetahuan akan komunikasi interpersonal, yaitu kekuasaan, identitas, dan hubungan. Dalam mempengaruhi anaknya untuk memutuskan berkuliah sambil bekerja tentunya orangtua menggunakan kekuasaan dalam keluarga, karena anak harus tunduk kepada otoritas, aturan, serta norma yang berlaku di dalam keluarga yang dimana dipegang kendali oleh orang tua. Selain hal tersebut, setiap orangtua akan memperhatikan identitas dari dirinya sendiri dan keluarga. Seperti halnya memperhatikan latarbelakang keluarga tersebut merupakan kaum berpendidikan, pengusaha, 
atau bahkan dari lapisan masyarakat yang biasa saja tapi memiliki harapan kepada anaknya. Selain itu, hubungan juga sangat dibutuhkan dalam keluarga.

Hubungan yang erat yang didapat dari komunikasi antara individu dengan anggota keluarga terlebih lagi antara orangtua dan anak dapat membentuk konsep diri seorang anak dalam memutuskan untuk berkuliah sambil bekerja. Konsep diri sendiri adalah citra seseorang tentang dirinya, dan terbentuk berdasarkan berbagai pengalaman dari interaksi dengan lingkungan. Hal ini merupakan sebuah aspek penting dalam diri individu, karena konsep diri seseorang merupakan sebuah tolak ukur dalam berinteraksi dengan lingkungan sekitarnya (Fauzan \& Supratman, 2019). Konsep diri yang terbentuk dengan baik akan semakin mempermudah anak dalam menentukan pilihannya untuk berkuliah sambil bekerja, karena tentunya tidak mudah bagi seorang anak untuk menentukan pilihan yang tepat. Jenjang perkuliahan yang dilalui tidaklah mudah apabila dijalani bersamaan dengan menggeluti pekerjaan.

Peran komunikasi dalam hal ini yaitu akan membantu orang tua untuk mendukung dan membimbing anaknya, sehingga timbulnya motivasi dalam diri anak untuk melanjutkan pendidikan. Hal ini sejalan dengan penelitian yang dilakukan oleh Tarmidi (2015), yang menyatakan bahwa ada hubungan positif antara dukungan sosial orangtua dengan kemandirian belajar pada siswa sekolah menengah atas. Dukungan orang tua merupakan sistem dukungan sosial yang terpenting di masa remaja.

Nilai Sig. pengaruh interaksi kelompok sebaya $\left(\mathrm{X}^{2}\right)$ terhadap strategi pengambilan keputusan berkuliah sambil bekerja (Y) adalah sebesar $0,172>0,05$ dan nilai t hitung $1,376<\mathrm{t}$ tabel 1,987, sehingga dapat disimpulkan bahwa H2 ditolak yang berarti tidak terdapat pengaruh antara interaksi kelompok sebaya $\left(\mathrm{X}^{2}\right)$ terhadap strategi pengambilan keputusan berkuliah sambil bekerja (Y).

Di usia remaja yang sedang mengalami kebingungan, sehingga mereka berusaha untuk mencari tempat untuk bergaul dan bertemu dengan teman-teman sebaya yang dapat memahami gejolak emosi serta tindakan yang dirasakan dirinya. Dalam kehidupan di usia remaja, teman sebaya merupakan sebuah faktor yang sangat berpengaruh. Menurut Harlock, anak usia remaja cenderung untuk menghabiskan waktu dengan kelompok sebayanya, oleh karena itu teman sebaya dapat mempengaruhi sikap, minat, dan bahkan perilaku lebih besar yang diberikan oleh keluarga (Sari, Hamiyati, \& Rasha, 2019). Di sisi lain berdasarkan hasil penelitian yang dilakukan, menghasilkan bahwa tidak ada pengaruh yang diberikan ketika anak usia remaja berinteraksi dengan teman 
Tabel 6 Uji F

ANOVA ${ }^{a}$

\begin{tabular}{llrrrrr}
\hline Model & & Sum of Squares & df & Mean Square & F & \multicolumn{1}{c}{ Sig. } \\
\hline 1 & Regression & 941,380 & 2 & 470,690 & 15,292 &, $000^{\mathrm{b}}$ \\
& Residual & 2647,092 & 86 & 30,780 & & \\
& Total & 3588,472 & 88 & &
\end{tabular}

a. Dependent Variable: Pengambilan Keputusan (Y)

b. Predictors: (Constant), Interaksi Kelompok Sebaya (X2), Komunikasi Interpersonal (X1)

sebayanya ketika ingin memutuskan untuk berkuliah sambil bekerja, meskipun kelompok sebaya berawal dari masa remaja dengan perkumpulan kecil, terisolasi, serta uniseks. Perkumpulan merupakan sebuah kelompok anak laki-laki dan perempuan yang tinggal di lingkungan yang sama, pergi ke sekolah yang sama, rumah ibadah yang sama, memainkan permainan yang sama, atau bahkan memiliki minat yang sama (Achilike, 2017).

Uji F dilakukan bertujuan untuk melihat pengaruh yang diberikan variabel bebas yang ada secara bersama-sama terhadap variabel terikat (Hidayat, 2013). Uji F yang dilakukan bertujuan untuk melihat pengaruh antara variabel komunikasi interpersonal orangtua dan anak $\left(\mathrm{X}^{1}\right)$ dan variabel interaksi kelompok sebaya $\left(\mathrm{X}^{2}\right)$ terhadap variabel strategi pengambilan keputusan berkuliah sambil bekerja (Y) secara simultan.

Berdasarkan hasil penghitungan diperoleh nilai signifikansi untuk pengaruh komunikasi interpersonal orangtua dan anak $\left(\mathrm{X}^{1}\right)$ dan interaksi kelompok sebaya $\left(\mathrm{X}^{2}\right)$ secara simultan terhadap strategi pengambilan keputusan berkuliah sambil bekerja (Y) adalah sebesar $0,000<0,05$ dan nilai $\mathrm{F}$ hitung 15,292 > F tabel 3,10, sehingga dapat disimpulkan bahwa H3 diterima yang berarti terdapat pengaruh komunikasi interpersonal orangtua dan anak $\left(\mathrm{X}^{1}\right)$ dan interaksi kelompok sebaya $\left(\mathrm{X}^{2}\right)$ secara simultan terhadap strategi pengambilan keputusan berkuliah sambil bekerja (Y).

\section{SIMPULAN}

Berdasarkan penelitian yang dilakukan peneliti pada variabel $\mathrm{X}^{1}$ mencapai kategori sangat baik. Pada $\mathrm{X}^{1}$ komunikasi interpersonal dijadikan sebagai variable $\mathrm{X}^{1}$ mengingat bahwa peneliti ingin melihat kondisi komunikasi interpersonal orangtua dengan anak di kalangan mahasiswa itu sendiri. Dapat diartikan bahwa mahasiswa/i Universitas Bunda Mulia menyetujui bahwa orang tua memiliki peranan 
penting dalam setiappengambilankeputusannya. Hasil ini memperlihatkan bahwa peran orangtua sangat dibutuhkan dalam mengontrol perilaku anggota keluarga dalam bertindak terutama dalam perilaku seorang anak. Setiap tindakan serta keputusan yang diambil oleh seorang anak harus berlandaskan pada aturan yang berlaku dalam keluarga. Aturan tersebut dibuat oleh orangtua sebagai pemegang kekuasaan yang harus dipatuhi oleh seluruh anggota keluarga, agar memudahkan untuk mengontrol setiap tindakan yang dilakukan anggota keluarga.

Berdasarkan penelitian yang dilakukan peneliti pada variabel $\mathrm{X}^{2}$ juga mencapai kategori yang baik. Pada $\mathrm{X}^{2}$ interaksi dalam kelompok atau teman sebaya dijadikan sebagai variabel $\mathrm{X}^{2}$ dikarenakan peneliti ingin melihat peran teman sebaya atau kelompok memiliki kapasitas atau peran dalam pengambilan keputusan seseorang. Mengacu pada hasil analisis di atas, dapat diartikan bahwa mahasiswa/i Universitas Bunda Mulia menyetujui bahwa interaksi teman sebaya atau sekelompok memiliki peran kurang penting dalam pengambilan keputusan seseorang. Dalam hal tersebut menyatakan bahwa peran orang tua memiliki andil lebih penting dibandingkan dengan peranan kelompok sebaya untuk memberi pengaruh individu ketika memilih berkuliah sambil bekerja.

Peneliti menyarankan agar pihak-pihak atau lembaga pemerintah yang memiliki kewenangan di bidang pendidikan tinggi, melakukan kampanye atau penyadaran pada orang tua tentang pentingnya pendidikan tinggi bagi anak. Dengan demikian diharapkan para orang tua tersebut dapat mendorong anak-anak mereka untuk memiliki jenjang pendidikan yang lebih tinggi (berkuliah).

\section{DAFTAR PUSTAKA}

Achilike, B. A. (2017). Review Article Influence of Peer Group on Adolescent Learning. International Journal Of Current Research, 9(3), 48449-48452.

Alawiyah, F. (2017). National Standards of Primary and Secondary Education. Aspirasi, 8(1), 81-92.

Aliyu, A. A., Bello, M. U., Kasim, R., \& Martin, D. (2014). Positivist and Non-Positivist Paradigm in Social Science Research: Conflicting Paradigms or Perfect Partners? Journal of Management and Sustainability, 4(3). https://doi.org/10.5539/jms.v4n3p79 Apuke, O. D. (2017). Quantitative Research Methods: A Synopsis Approach. Kuwait Chapter of Arabian Journal of Business and Management Review, 6(11), 40-47. https://doi.org/10.12816/0040336

Arkandito, G. F., Maryani, E., Rahmawan, D., \& Wirakusumah, T. K. (2019). Komunikasi Verbal Pada Anggota Keluarga Yang Memiliki Anak Indigo. Jurnal Manajemen Komunikasi, 1(1), 42-56. https://doi. org/10.24198/jmk.v1i1.9955

Banerjee, A., \& Chaudhury, S. (2010). Statistics without tears: Populations and samples. Industrial Psychiatry Journal, 19(1), 60. https://doi.org/10.4103/0972-6748.77642

Dina, F., Hadi, S., \& Rusmawati, D. (2019). 
Hubungan Antara Keharmonisan Keluarga Dengan Konsep Diri Pada Siswa Kelas Xi Sma Negeri 1 Demak. Empati, 8(2), 26-32. Elfil, M., \& Negida, A. (2017). Sampling methods in Clinical Research; an Educational Review. Emergency (Tehran, Iran), 5(1), e52. https://doi.org/10.22037/ emergency.v5i1.15215

Fauzan, M. F., \& Supratman, L. P. (2019). Studi Fenomenologi Tentang Komunikasi Antarpribadi Anggota Komunitas Anak Indigo Indonesia. Jurnal Manajemen Komunikasi, 1(2), $180 . \quad$ https://doi. org/10.24198/jmk.v1i2.11684

Ghozali, I.(2016). Aplikasi Analisis Multivariate dengan Program IBM SPSS 23 (8th ed.). Badan Penerbit Universitas Diponegoro.

Hair, J., Black, W., Babin, B., \& Anderson, R. (2014). Multivariate Data Analysis (MVDA). In Pharmaceutical Quality by Design: A Practical Approach. Pearson Educated Limited. https://doi. org/10.1002/9781118895238.ch8

Handayani, M. (2016). Peran Komunikasi Antarpribadi Dalam Keluarga Untuk Menumbuhkan Karakter Anak Usia Dini. Jurnal Ilmiah VISI PPTK PAUDNI, 11(1), 57-64.

Heale, R., \& Twycross, A. (2015). Validity and reliability in quantitative studies. EvidenceBased Nursing, 18(3), 66-67. https://doi. org/10.1136/eb-2015-102129

Hidayat, A. (2013). Uji F dan Uji T. Statistikian. Hutapea, E. B. (2015). Representasi Simbolsimbol Komunikasi Menjadi Realitas. BRICOLAGE: Jurnal Magister Ilmu Komunikasi, 1(2), 1-26.

Kementerian Pendidikan dan Kebudayaan. (2016). Peraturan Menteri Pendidikan dan Kebudayaan RI Tahun 2016 tentang Program Indonesia Pintar. 2-5.
Khurana, A., Bleakley, A., Jordan, A. B., \& Romer, D. (2015). The Protective Effects of Parental Monitoring and Internet Restriction on Adolescents' Risk of Online Harassment. Journal of Youth and Adolescence, 44(5), 1039-1047. https:// doi.org/10.1007/s 10964-014-0242-4

Kivunja, C., \& Kuyini, A. B. (2017). Understanding and applying research paradigms in educational contexts. International Journal of Higher Education, 6(5), 26. https://doi.org/10.5430/ijhe. v6n5p 26

Kuntaraf, K., \& Kuntaraf, J. (1999). Komunikasi Keluarga. Indonesia Publishing House.

Laksana, S. D. (2005). Integrasi Empat Pilar Pendidikan (UNESCO) Dan Tiga Pilar Pendidikan Islam. 43-61.

Malhotra, N. (2010). Marketing research (1st ed.). Pearson.

Marta, R. F., Fernando, J., \& Simanjuntak, R. F. (2019). Eksplikasi Kualitas Konten Peran Keluarga Pada Instagram @KEMENPPPA. Journal of Communication, 4(2).

Marvasti, A. (2018). Research methods. The Cambridge Handbook of Social Problems, 1(3), 23-37. https://doi. org/10.1017/9781108656184.003

Moore, J. (2017). Where Is the Critical Empirical Interpersonal Communication Research? A Roadmap for Future Inquiry into Discourse and Power. Communication Theory, 27(1), 1-20. https://doi.org/10.1111/comt.12107

Muhardi. (2005). Kontribusi Pendidikan Dalam Meningkatkan Kualitas Bangsa Indonesia. Journal Unisba, XX(4), 478-492. https:// doi.org/10.29313/mimbar.v20i4.153

Nurkholis. (2013). Pendidikan Dalam Upaya Memajukan Teknologi. Jurnal Kependidikan, 1(1), 24-44. file://C:/Users/ Diana/Downloads/530-Article Text-1025- 
1-10-20160318.pdf

Sari, I. A., Hamiyati, H., \& Rasha, R. (2019). Pengaruh Fungsi Peer Group Terhadap Pengambilan Keputusan Pembelian (Pencarian Informasi) Produk Kosmetik Pada Remaja Putri. JKKP (Jurnal Kesejahteraan Keluarga Dan Pendidikan), 6(01), 1-8. https://doi.org/10.21009/ jkkp.061.01

Sasongko, Y. P. D., \& Marta, R. F. (2018). Ekspresi Identitas Melalui Relasi Ayah Dan Anak Pada Iklan Youtube Grab Official. Bricolage: Jurnal Magister Ilmu Komunikasi, 4(02), 118. https://doi. org/10.30813/bricolage.v4i02.1656

Sasson, H., \& Mesch, G. (2017). The Role of Parental Mediation and Peer Norms on the Likelihood of Cyberbullying. Journal of Genetic Psychology, 178(1), 15-27. https:// doi.org/10.1080/00221325.2016.1195330

Siregar, N. S., Wasidi, W., \& Sinthia, R. (2018). Hubungan Antara Komunikasi Interpersonal Orang Tua Dan Anak Dengan Perilaku Kenakalan Remaja. Consilia: Jurnal Ilmiah Bimbingan Dan Konseling, 1(1), 26-35. https://doi.org/10.33369/ consilia.1.1.26-35

Sophya, I. V. (2014). Desain Pembelajaran Bahasa Inggris Untuk Pendidikan Anak Usia Dini. ThufuLA: Jurnal Inovasi Pendidikan Guru Raudhatul Athfal, 2(2), 251. https://doi.org/10.21043/thufula. v2i2.4639

Stankevich,A. (2017). Explaining the Consumer Decision-Making Process: Critical Literature Review. Journal of International Business Research and Marketing, 2(6), 7-14. https://doi.org/10.18775/ jibrm.1849-8558.2015.26.3001

Sugiyono. (2015). Metode Penelitian Bisnis. Bandung: Alfabeta.
Sutanta. (2019). Beljar Mudah Metodologi Penelitian (I-2019). Yogyakarta: Thema Publishing.

Tarmidi, T. (2015). Korelasi Antara Dukungan Sosial Orang Tua dan Self-Directed Learning pada Siswa SMA. Korelasi Antara Dukungan Sosial Orang Tua Dan Self-Directed Learning Pada Siswa SMA, 37(2), 216-223. https://doi.org/10.22146/ jpsi.7733

Thoharudin, M., Suryanti, Y., \& Sore, A. D. (2019). Sosialisasi Pentingnya Pendidikan Lebih Tinggi Di Desa Sungai Mali Kecamatan Ketungau Hilir. Jurnal Pengabdian Masyarakat Khatulistiwa, 2(1), 1-9. https://doi.org/10.31932/jpmk. v2i1.423

Turabik, T., \& Baskan, G. A. (2015). The Importance of Motivation Theories in Terms Of Education Systems. Procedia Social and Behavioral Sciences, 5. https:// doi.org/10.1016/j.sbspro.2015.04.006

Umar, Hassan Sa'id and Usman, M. (2015). The Imperative of Population Sampling in Social Science Research. Global Journal of Political and Science and Administration, 3(3), 49-57.

Wijaya, H. (2018). Peranan Teori Pendidikan dalam Mengatasi Anak Putus Sekolah Di Indonesia.

Williamson, K. (2018). Populations and samples. In Research Methods: Information, Systems, and Contexts: Second Edition. Elsevier Ltd. https://doi.org/10.1016/ B978-0-08-102220-7.00015-7

Yusriyah, K., Fatoni, A., \& Mansyur, M. A. (2020). Communication Networks Analysis On Information Dissemination Of The Moving Of Capital City From Jakarta To East Kalimantan. ASPIRATION Journal, (May), 31-55. 